\title{
On the Changing Structure of International Investment Law: The Human Right to Water and ICSID Arbitration
}

\author{
Fabrizio Marrella* \\ Professor of International Law, University Cà Foscari, Venice, Italy \\ Director, European Inter-University Center for Human Rights and Democratisation, \\ Venice, Italy
}

\begin{abstract}
Water is the world's third largest industry after oil and energy power. Although clean drinking water and sanitation are necessary for the health and development of individuals and communities, even today, billions of people lack access to either. In response to these concerns, the international community has set a Millennium Development Goal (MDG) of providing, by 2015, clean water and improved sanitation to at least half of the people worldwide who now lack these services. Water is treated both as a public good and an economic good. In the last decade, we have witnessed the commoditisation through privatization and liberalisation of an essential good for each individual's life. Transnational corporations may encounter water issues in at least three different contexts: a) as enablers of access to water; b) as providers or distributors of water and c) as a user or consumer of water. Many initiatives have been developed within the United Nations such as the Global Compact and the appointment of both an independent expert on human rights obligations related to access to safe drinking water and sanitation and a Special Representative of the Secretary General on business and human rights. Both of them are mainstreaming human rights in the business sector reconciling different forms of regulations. The right to water has come into discussion in a number of ICSID arbitrations and other cases are still pending. The purpose of this article is to discuss the advancement of the thinking in this field so that it could be applied in arbitration practice.
\end{abstract}

Keywords

right to water; human rights; ICSID arbitration

\section{Introduction}

Water is the world's third largest industry after oil and energy power. Although clean drinking water and sanitation are necessary for the health and development of individuals and communities, even today, billions of people lack access to either. In response to these concerns, the international community has set a Millennium Development Goal (MDG) of providing, by 2015, clean water and improved sanitation to at least half of the people worldwide who now lack these services.

Even before the present world financial markets crisis, the water and sanitation infrastructure sector, were at the centre of many problems: freshwater scarcity 
and growing demand; underinvestment in infrastructure in both developed and developing countries; corruption; and controversy over the appropriate roles of the public and private sectors in ownership of water resources and responsibility for service delivery.

The impact of economic globalisation on the right to water carries the high likelihood of being negative particularly for the most marginalised in societies. Too often human rights concerns have been kept apart from, or simply forgotten in policy domains that shape business practices, including commercial policy, investment policy and corporate governance. This is especially true when major capital investments are needed to bring water to urban and rural populations and it is a primary duty to the State to do them, with or without the help of private parties.

Water is treated both as a public good and an economic good. In the last decade, we have witnessed the commoditisation through privatization and liberalisation of an essential good for each individual's life. In this perspective, an assessment of the gradual convergence of International Economic Law with the human right to water has become unavoidable.

If water is essential for human survival (water contamination, inter alia, weakens or destroys natural ecosystems that support human health, food production, and biodiversity), then it is logical to consider access to water as a human right. How should this right then be protected, respected and fulfilled by States? Proponents of market-based solutions believe that putting a price on water and allowing the private sector to deliver water services is the most efficient way to maintain water resources and bring new capital to the sector. Advocates of water as a public good, on the other hand, emphasize the unique characteristics of water and the market failures (actual or potential) to deliver water to the poor, not to speak about the ecological and non-economic values of water. Therefore, in the latter case, water should be the object of a State monopoly under strict regulation and full transparency management.

Recent international practice has evidenced that some investment treaties and State contract provisions may unduly constrain the host Government's ability to achieve its policy objectives, including its international human rights obligations. ${ }^{1}$ That is because under threat of taking the host State to binding international arbitration, a foreign private investor may end up being able to obtain significant advantages in terms of regulation, or seek compensation from the Government for the cost of compliance. At the same time, however, the right to regulate by the State must be consistent with the private investors' need for predictability, rule of law, treatment, protection and guarantee about the actions of the host State, including compensation in the event of expropriation.

1) For a general discussion see W. Benedek, K. De Feyter and F. Marrella, Economic Globalisation and Human Rights (2007); D. Carreau and P. Jolliard, Droit international économique, Paris: Dalloz, 4th edition, 2010. 
Every State needs foreign private investments and, therefore, providing effective investor protection is necessary for maintaining FDI. How can these competing interests be balanced between investors and host States so that both of them will benefit from it? How can non-investors, i.e., the common people, avoid paying the negative externalities of such an operation when a State fails to exercise its regulatory powers over water?

It is not the purpose of this article to provide the final solution to such a complex problem, nor is it possible to debate the merits of private versus public ownership of water service utilities. Rather, this article will first discuss the right to water as a human right and its impact on corporations 'activities. Then reference will be made to the impact of ICSID arbitration on the right to water and to the possibilities of balancing different interests at stake.

\section{The Right to Water as a Human Right}

Notwithstanding the intuitive importance of water within the most vital human rights, it may be surprising to see that very few express references may be found in fundamental international instruments. For any reasonable human being, every individual should hold a right to access adequate and drinking water while, under international law, national Governments should ensure that water is available, without discrimination to the population present in their territory. Is the right to water the product of some academics, a matter of logics or a rule of positive law? The legal framework is particularly complex although the great majority of commentators speak easily of the right to water as a human right. ${ }^{2}$ As a matter of facts, an express reference to it is quite rare in international human rights law instruments.

2) See: F. Marrella, "Regolazione internazionale e responsabilità globale delle imprese transnazionali", 3 Diritti Umani e Diritto Internazionale (2009) 229-258; F. Marrella, F. Galgano, Diritto e prassi del commercio internazionale (2010); Benedek et al., Economic Globalisation and Human Rights (2007); M. Fitzmaurice, "The Human Right to Water", Fordham Environmental Law Review (2007)538-586; J. Razzaque, "Trading Water: the Human Factor", Review of European Community and International Environmental Law (2004) 15-26; A. Tanzi, "Controversial Developments in the Field of Public Participation in the International Environmental Law Process", in P.-M. Dupuy and L. Vierucci (eds.), NGOs in International Law: Efficiency in Flexibility? (2008), pp. 135-152; A. Tanzi and C. Pitea, Emerging Trends in the Role of Non-State Actors in International Water Disputes, in Resolution of international water disputes: papers emanating from the Sixth PCA International Law Seminar (8 November 2002), 2003, pp. 259-297; Stan Bernstein, "Freshwater and Human Population: A Global Perspective," in Karin M. Krchnak (ed.), Human Population and Freshwater (2002), pp. 149-157, available at: http://environment. yale.edu/documents/downloads/0-9/107Bernstein.pdf; T. Treves, M. Frigessi di Rattalma, A.Tanzi, A. Fodella, C. Pitea and C.Ragni (eds.), Civil Society, International Courts and Compliance Bodies (2005); T. Treves, L. Pineschi, A. Tanzi, C. Pitea, C. Ragni and F. Romanin Jacur (eds.), Non-Compliance Mechanisms and Procedures and the Effectiveness of International Environmental Agreements (2009). 
At the global level, the Universal Declaration of Human Rights ${ }^{3}$ and the 1966 International Covenant on Economic, Social and Cultural Rights, ${ }^{4}$ are very timid on the point. The latter, foresees, it Art. 11, a right to "an adequate standard of living... including adequate food, clothing and housing, and to the continuous improvement of living conditions" to which it is added, at Art. 14(2)(c), a provision of "adequate nutrition and safe drinking water".

A more concrete development, although contained in a soft law instrument may be found in General Comment n.15 of the UN Committee on International Covenant on Economic, Social and Cultural Rights of 26 November 2002 (E/C.12/2002/11) on the right to water. According to the General Comment, the right to water is derived from that of every individual to an adequate standard of living (Art. 11) and the right to health (Art. 12).

As a matter of facts, Art. 11, para 1, of the ICESCR specifies a number of rights emanating from, and indispensable for, the realization of the right to an adequate standard of living "including adequate food, clothing and housing". The use of the word "including" thus indicates that this catalogue of rights was not intended to be exhaustive. Moreover, the right to water is presupposed for securing an adequate standard of living since it is one of the most fundamental conditions for survival. In addition, the right to water is inextricably related to the right to the highest attainable standard of health (Art. 12, para. 1) and the rights to adequate housing and adequate food (Art. 11, para. 1). All in all, the right to water may be considered as a pillar where the right to life and human dignity are to be constructed.

Even in other international instruments such as the 1966 International Convention on the Elimination of All Forms of Racial Discrimination, ${ }^{5}$ the 1979 Convention on the Elimination of All Forms of Discrimination against Women, ${ }^{6}$ the 1989 Convention on the Rights of the Child ${ }^{7}$ and the 2006 Convention on the Rights of Persons with Disabilities, express references, where they exist, are very timid.

It should not therefore be surprising to note that more food for thought is found into declarations and international programmes with regard to access to safe drinking water and sanitation adopted by major United Nations conferences and summits, and by the General Assembly at its special sessions and during follow-up meetings, inter alia, the Mar del Plata Action Plan on Water Development and Administration, adopted at the United Nations Water Conference in

\footnotetext{
3) See Art. 25 of the UDHR where it is envisaged in broad terms "a standard of living adequate for the health and wellbeing... including food, clothing, housing".

4) 993 UNTS 3.

5) 660 UNTS 195.

๑) 1249 UNTS 13. See Art. 14(2)(h) where it it speaks of "adequate living conditions", particularly in relation to housing, sanitation, electricity and water supply.

7) 1577 UNTS 3. See Art 24(2)(c) where the convention provides "to combat disease and malnutrition... through the provision of adequate nutritious foods and clean drinking-water".
} 
March 1977, Agenda 21, adopted at the United Nations Conference on Environment and Development in June 1992, and the Habitat Agenda, adopted at the second United Nations Conference on Human Settlements in $1996 .{ }^{8}$

All in all the most important achievement at this level is the inclusion of this issue amongst the Millennium Development Goals, stressing, in that context, the resolve of Governments to halve, by 2015 the proportion of people unable to reach or afford safe drinking water, and to halve the proportion of people without access to basic sanitation, as agreed in the Johannesburg Plan of Action.

The situation looks slightly different on a regional scale. Reference here, may be made to the Protocol on Water and Health, adopted by the United Nations Economic Commission for Europe in 1999, ${ }^{9}$ the European Charter on Water Resources, adopted by the Council of Europe in 2001, the Abuja Declaration, adopted at the first Africa-South America summit in 2006, the message from Beppu, adopted at the first Asian-Pacific Water Summit in 2007, the Delhi Declaration, adopted at the third South Asian Conference on Sanitation in 2008, and the Cairo Declaration, adopted at the fifteenth summit of Heads of State and Government of the Non-Aligned Movement in 2009.

Finally, one should note that in recent years specific constitutional norms have been introduced in at least ten countries, reinforcing via domestic law the importance of the right to water and, as such, evidencing that international rules on the right to water as a human right should be placed high in the Governments' agenda.

Such constitutional solutions look quite different. ${ }^{10}$ On one extreme of the scale, one may place the amendment to the Uruguay constitution of 2004 where private investment in water services is made unconstitutional per se, in order to protect the human right to water while Ecuador has made privatization of water services unconstitutional but providing at the same time a transition clause for the Bechtel subsidiary InterAgua to transfer operations back to the public sector. Bolivia and Colombia are elaborating provision on the human right to water, and India and Argentina have recognized this right through interpretations of other constitutional provisions - the right to life and the right to a healthy environment, respectively. In South Africa, the national constitution provides for a right to water and the High Court has confirmed the nature of human right of it. ${ }^{11}$

\footnotetext{
8) See the Resolution of the Human Rights Council adopted on 12 October 2009 on Human Rights and access to safe drinking water and sanitation, Doc. A/HRC/RES/12/8.

9) See http://www.unece.org/env/water/text/text_protocol.htm (visited on 20 May 2010).

10) See The Center for Economic and Social Rights, The Right of Access to Water: Relevant Constitutional Provisions. (Listing: Ethiopia, Gambia, Guatemala, Panama, Uganda, South Africa, Venezuela, and Zambia.). See in particular Uruguay Constitution (2004), Art. 47, 188. See also Ecuador's Constitution (2008), Arts. 13, 41 and transitoria 4.

11) See Lindiwe Mazibuk, and Others v. Johannesburg Water and Others, South African High Court, Witwatersrand Local Division, Case no: 06/13865 (July 7, 2007) and in particular P. Bond, J. Dugard, "The case of Johannesburg water: what really happened at the pre-paid 'Paris pump"', in Law, Democracy and Development, at http://www.ukzn.ac.za/ccs/files/Bond\%20Dugard\%20LDD.pdf (visited on 15 May 2010).
} 
India has reached a similar result only via case law, ruling that private corporations violating the human right to water can be held liable. ${ }^{12}$

Confronted with the (poor) legal landscape that has been sketched above, the UN Human Rights Council adopted a decision (in Nov 2006) and a resolution (in Sept 2007) regarding human rights and equitable access to safe drinking water and sanitation. In March 2008, the Human Rights Council by its resolution $7 / 22$, decided to appoint an independent expert on the issue of human rights obligations related to access to safe drinking water and sanitation. Accordingly at its September 2008 session, the Human Rights Council appointed Ms. Catarina de Albuquerque (Portugal) as an independent expert for a period of three years. She took up her function on 1 November 2008 and her work is currently ongoing.

Her work, together with that of the Special Representative of the Secretary General on business and human rights - to which reference will be made hereinafter - will contribute to get the International Community moving towards the accomplishment of, inter alia, Millennium Development Goal 7. This Goal is intended to halve, by 2015, the proportion of people who are unable to reach, or to afford, safe drinking water; and to stop the unsustainable exploitation of water resources, by developing water management strategies at the regional, national and local levels, which promote both equitable access and adequate supplies.

Five normative criteria for the full realization of the right to water have been identified (availability, accessibility, quality/safety, affordability, acceptability) with five cross cutting ones (non-discrimination, participation, accountability, impact, sustainability).

Availability refers to sufficient quantities, reliability and the continuity of supply. In other words, water should be available and in a sufficient quantity for meeting personal and domestic requirements of drinking and personal hygiene as well as for further personal and domestic uses such as cooking and food preparation, dish and laundry washing and cleaning. There must also exist sufficient number of sanitation facilities (with associated services) within, or in the immediate vicinity, of each household, health or educational institution, public institution and place, and the workplace.

Water, then, should be accessible. This means that sanitation and water facilities are physically accessible, at day and night, for everyone within, or in the immediate vicinity, of each household, health or educational institution, public institution and the workplace. ideally within the home, including for people with special needs.

12) Indian Supreme Court in M C Mehta v. Union of India 2004 (12) SCC118, about Coca Cola operations in Kerala. 
Thirdly, access to sanitation and water facilities and services must be affordable, i.e., accessible at a price all people can pay. Paying for services, including construction, cleaning, emptying and maintenance of facilities, as well as treatment and disposal of faecal matter, must not limit people's capacity to acquire other basic goods and services, including food, housing, health and education guaranteed by other human rights. This also means that the State is obliged to ensure the provision of services free of charge (e.g., through social tariffs or crosssubsidies) for those who are genuinely unable to pay for sanitation and water through their own means.

Fourthly, sanitation facilities must be hygienically safe to use. They must also take into account the safety needs of peoples with disabilities, as well as those of children. Regular maintenance and cleaning are essential for ensuring the sustainability of sanitation facilities and continued access. Water must be of such a quality that it does not pose a threat to human health. Transmission of waterborne diseases via contaminated water must be avoided.

Finally, water and sanitation facilities and services must be culturally and socially acceptable. Acceptability means also privacy, as well as separate facilities for women and men in public places, and for girls and boys in schools. In regard to water, apart from safety, water should also be of an acceptable colour, odour and taste.

Five other parameters are to be considered cross-cutting ones. The first one is non discrimination. As indicated by treaty law, discrimination on race, colour, sex, age, language, religion, political or other opinion, national or social origin, property, birth, physical or mental disability, health status or any other civil, political, social or other status must be avoided, both in law and in practice. Individuals and groups potentially vulnerable or marginalized include: women, children, inhabitants of (remote) rural and deprived urban areas as well as other people living in poverty, refugees and IDPs, minority groups, indigenous groups, nomadic and traveller communities, elderly people, persons living with disabilities, persons living with HIV/AIDS or affected by other health conditions, people living in water scarce-regions and sanitation workers amongst others.

Secondly, processes related to planning, design, construction, maintenance and monitoring of sanitation and water services should be participatory. This requires, inter alia, including representatives of all concerned individuals, groups and communities in the decision making processes. To allow for participation in that sense, transparency and access to information is essential. Last but not least, accountability should be always guaranteed.

The realization of the human right to water requires responsive and accountable institutions, with a clear designation of responsibilities and coordination between different entities involved. In addition to participation and access to information mentioned above, communities should be able to participate in monitoring and evaluation as part of ensuring accountability. 
In cases of violations - be it by States or non-State actors -, States have to provide accessible and effective judicial or other appropriate remedies at both national and international levels. Victims of violations should be entitled to adequate reparation, including restitution, compensation, satisfaction and/or guarantees of non-repetition.

\section{Transnational Corporations, the Right to Water and the Evolving International Agenda}

Transnational corporations may encounter water issues in at least three different contexts:
a) as enablers of access to water;
b) as providers or distributors of water and
c) as a user or consumer of water.

Leaving aside this latter aspect, one may note that Human Rights may be violated by a company if its facilities pollute the surroundings affecting ipso facto the rights to a home, to health of persons and the environment. ${ }^{13}$ Also, as a preliminary note, it should be observed that, in the framework of the European Convention on Human Rights, it is now settled that companies and their shareholders benefit from human rights protection against the host State in which they operate. ${ }^{14}$

Such aspects have grown in importance in the last decade, due to the fact that many States have conducted for various reasons (mostly under the push of the International Monetary Fund or the World Bank) large privatization policies. Have then they privatised the international obligations they had in terms of protecting, respecting and fulfilling human rights, including the right to water of the people? The answer is negative.

\footnotetext{
13) Art. 8 of the ECHR seems to covers such a situation (EctHR, Lopez Ostra v. Spain, 9 December 1994). The Court sayed the State did not succeed in striking a fair balance betw. the interest of the town (having a waste-treatment plan) and the applicant's enjoyment of her right to respect for her home and her private and family life.

14) On shareholder rights under ECHR law in general see: Agrotexim Hellas $S A$ and Others v. Greece A 330 (1995); (1996) 21 EHRR 250; Association and H. v Austria (1984) 36 DR 187 at 191-2; Matos e Silva Lda and Others v. Portugual 1996-IV 1092; (1997) 24 EHRR 573; Société Colas Est et autres v. France 2002-III 421; Autronic AG v. Switzerland A 178 (1990); (1990) 12 EHRR 485; Demuth v Switzerland 2002-IX 704; (2004) 38 EHRR 20; Comingersoll SA v. Portugal 2000-IV 355; (2001) 31 EHRR 772. On shareholder rights under Protocol 1(1) in particular: Olczak v. Poland, Decision of November 7, 2002, EHRR 2002-X 61; Company S-S I AB and BT v. Sweden, Application 11189/84 (1986) 50 DR 121, 138; Bramelid and Malmström v. Sweden, Application 8588-89/79 (1982) 29 DR 64, 81; (1983) 5 EHRR 249. For an extensive analysis see Marius Emberland, The Human Rights of Companies: Exploring the Structure of ECHR Protection (2006), pp. 65 et seq.
} 
Privatization consists in hiring private enterprises to carry out public service functions. Its aim is, theoretically, to bring market efficiency and new sources of capital to under-funded and poorly managed public enterprises. Sometimes, this operation may replace a state-owned monopoly with a private one. Thus, if not carefully considered, the economic cure may only displace the problem of realising the right to water for all, from the realm of politics and public decision-making to the realm of markets and private profit seeking. ${ }^{15}$

In the last decade, we have also witnessed the phenomenon of a shift towards private sector for UN projects financing. The creation and the founding of the Global Compact has become a new paradigma in International Law and the main avenue of persuading transnational corporations to act responsibly. The human rights and business framework with the Global Compact as its zenith, has developed over a number of decades, beginning with the 1976 Organization for Economic Development and Cooperation (OECD) Guidelines for Multinational Enterprises; ${ }^{16}$ the 1977 International Labour Organization (ILO) Tripartite Declaration of Principles Concerning Multinational Enterprises and Social Policy; ${ }^{17}$ the United Nations Commission on Transnational Corporations' code of conduct initiated in the 1970s and abandoned in $1994 ; ;^{18}$ and the contentious United Nations "Norms on the Responsibilities of Transnational Corporations and Other Business Enterprises with Regard to Human Rights", ${ }^{19}$ which was abandoned in $2004 .^{20}$

The United Nations Global Compact is the result of the call launched by the United Nations Secretary General Kofi Annan in 1999 at the World Economic Forum. Under this scheme, member corporations and organisations can sign up to the Global Compact and report on their compliance with its ten principles relating to labour, human rights, anti-corruption and the environment. ${ }^{21}$ It is designed to promote 'responsible corporate citizenship' and has over 5,200 corporate members worldwide.

\footnotetext{
15) See for example J. Stiglitz, Making Globalization Work (2006).

16) Part of the OECD Declaration and Decisions on International Investment and Multinational Enterprises, updated June 2000.

17) Adopted November 1977, 204th Session, amended November 2000, 279th Session (2001), <http:// www.ilo.org/public/english/employment/multi/download/english.pdf>.

18) One may add in such a framework the 1977 Code of Conduct for Companies Operating in South Africa during apartheid which was adopted by the European Economic Communities, see U.N. Doc. $\mathrm{A} / 32 / 267$.

19) See U.N. Econ. \& Soc. Council (ECOSOC), Sub-Comm. On Promotion and Protection of Human Rights, The United Nations Norms on the Responsibilities of Transnational Corporations and Other business Enterprises with Regard to Human Rights, U.N. Doc. E/CN.4/Sub.2/2003/12/Rev.2 (26 August 2003).

20) Responsibilities of Transnational Corporations and Other business Enterprises with Regard to Human Rights, C.H.R. Res. 2004/116, U.N. ESCOR, Commission on Human Rights, 60th Session, U.N. Doc. E/CN.2/2004/L.73/Rev.1 (2004).
}

21) $<$ http://www.unglobalcompact.org $>$. 
The UN envisage the Global Compact as a dialogue forum to promote mutual learning amongst corporations. The focus is essentially on helping corporations learn about 'best practices' and elaborating codes of conduct. This codes, however, in their general form, lack of strong law enforcement mechanisms. They are based more on peer-to-peer and market mechanisms: if member companies break the codes of conduct, the main sanction is a delisting from the Global Compact. By the same instrument, companies pledge to report regularly on how they are implementing the Compact's codes. To demonstrate progress, members use the Global Compact's "Communication on Progress", which is designed to highlight companies' information in CSR reports.

The flipside of the coin is that by encouraging corporate 'best practices' mutual learning and voluntary respect for human rights, the UN and its Member States avoid tackling the hot issue of concrete action at the international hard law level against corporate human rights violations. The result has been, nonetheless, in many cases positive but, here again, without a clear leadership and UN-driven regulatory framework, there is a risk to allow some companies to wrap themselves in the blue flag of the United Nations without increasing effectively human rights protection, particularly in the case of water. ${ }^{22}$

The issue of water is addressed by the Global Compact through the CEO Water Mandate, a voluntary initiative that is designed to assist companies in the development, implementation and disclosure of water sustainability policies and practices. ${ }^{23}$ Like the Global Compact, the CEO Water Mandate is based on a set of core elements that members claim to adhere to through a series of non-binding pledges (Direct Operations; Supply Chain and Watershed Management; Collective Action; Public Policy; Community Engagement; and Transparency). ${ }^{24}$ Members are all encouraged to learn from other 'best practices'. Most of the Mandate's endorsers are major corporations that are reliant on water as a primary input. Endorsers include Suez, Coca-Cola, PepsiCo, Nestlé, Groupe Danone, Unilever, Dow Chemical, Levi Strauss and Hindustan Construction Co.

In 2005, besides the Global Compact and following the failed adoption by States of the "Norms on the Responsibilities of Transnational Corporations and

22) See the critical views expressed by R. Girard in http://www.polarisinstitute.org/files/UNreport.pdf (visited on 15 May 2010).

23) The mission statement is as follows: "The CEO Water Mandate seeks to make a positive impact with respect to the emerging global water crisis by mobilizing a critical mass of business leaders to advance water sustainability solutions - in partnership with the United Nations, civil society organizations, governments, and other stakeholders. As a special initiative of the UN Secretary-General, The CEO Water Mandate offers a unique action platform to share best and emerging practices and to forge multistakeholder partnerships to address the problems of access to water and sanitation. The CEO Water Mandate covers six areas: Direct Operations; Supply Chain and Watershed Management; Collective Action; Public Policy; Community Engagement; and Transparency. Endorsers of The CEO Water Mandate recognize that through individual and collective action they can contribute to the vision of the UN Global Compact and the realization of the Millennium Development Goals". See http://www.unglobalcompact.org/issues/Environment/CEO_Water_Mandate/.

24) Id. 
Other Business Enterprises with Regard to Human Rights", the UN SecretaryGeneral to appoint a Special Representative for Business and Human Rights, ${ }^{25}$ Prof. John Ruggie (hereinafter SRSG) who had played a great role in the design of the Global Compact.

After extensive research, Prof. Ruggie in 2008 elaborated a framework based on three core principles: protect, respect and remedy. ${ }^{26}$

The first principle is the state duty to protect against human rights abuses by third parties, including business, through appropriate policies, regulation, and adjudication. The second principle is the corporate responsibility to respect human rights. In addition to compliance with applicable laws, companies are subject to what is sometimes called a social license to operate - or prevailing social expectations. The third principle is the need for more effective access to remedies for victims of human rights abuses involving companies. Even where institutions operate optimally, disputes over adverse human rights impacts of companies are likely to occur, and victims need redress. These (non binding) findings have been widely accepted both from Governments and from the business side.

However, it should not be forgotten that it is the task of the state to protect people within its frontiers against human rights infringements by non-state players. Privatization of essential goods and services does not amount to privatizing international responsibility. Human rights covenants are international legal conventions, agreements between countries making contracting states responsible for implementation of human rights. Countries which have mutually undertaken to protect, respect, fulfil and enforce human rights described in international human rights conventions have to implement these rules through national practice. In this regard, those states which are not in a position to implement and enforce human rights effectively should be helped more by the International Community in order to build up the appropriate judicial and administrative structures. ${ }^{27}$

A particular regulatory challenge, therefore, remains for business activity of companies in so-called weak governance zones. Weak governance zones are characterised by violence, corruption, deficient administrations and arbitrary political decisions, all factors which are condemned by the same international business community since they hinder business activity, complicate planning and make investments extremely risky.

25) Human Rights Resolution 2005/69, <http://www.business-humanrights.org>.

26) Protect, Respect and Remedy: A Framework for Business and Human Rights, Report of the Special Representative of the Secretary-General, John Ruggie, U.N. GAOR, Human Rights Council, 8th Session, Agenda Item 3, U.N. Doc. A/HRC/8/5 (2008).

27) In his 2008 report, John Ruggie singled out the OECD guidelines for multinationals as the most widely applicable standard confirmed by governments. In his view, these guidelines should be reviewed, because they are too unspecific on human rights and fall short of many voluntary business standards. However, it should be noted that OECD national contact points fulfill an important function amongst non-judicial remedies, as recognized by Prof. Ruggie in his latest reports. 
Those (few) multinational companies that have invested in a weak governance zone face a dilemma: they may help to improve the situation locally thanks to their investments, such as through measures against child labour, discrimination, inadequate pay, despite an unstable situation. Or, on the contrary, they may face the accusation that their business involvement can sometimes give indirect support to an illegitimate or a dictatorial regime with the result of contributing to the perpetuation of unacceptable conditions. In such a context, training of key company officers in Human Rights and the ability to implement codes of conduct becomes a strategic asset both for the company and for its external stakeholders. All in all, infringement of human rights and the absence of rule of law are massively detrimental to business activities and hence also impede companies with multinational operations.

Also in this perspective, the duty to respect becomes crucial. It is the duty of companies to respect human rights and to put in place the necessary management structures to this end. Companies have an important role to play in supporting and spreading human rights. The Universal Declaration of Human Rights calls on every individual as well as all sections of society, i.e. also including business players, to help realize human rights. At the same time, companies themselves have a responsibility to respect human rights, which exists independently of states. Corporate Social Responsibility begins with legal compliance and goes beyond compliance with host State law, especially when the law is enforced poorly or not at all. For these reasons, and also for a company to be able to demonstrate that it respects rights beyond legal requirements, a human rights due diligence process is nowadays indispensable.

"Naming and shaming" is a response by external stakeholders to the failure of companies to respect human rights. "Knowing and showing" is the new paradigma, meaning internalization of that respect by companies themselves through human rights due diligence analysis. ${ }^{28}$

According to the SRSG, the duty to respect entails the following:

Companies should consider three sets of factors. The first is the country contexts in which their business activities take place, to highlight any specific human rights challenges they may pose. The second is what human rights impacts their own activities may have within that context - for example, in their capacity as producers, service providers, employers, and neighbours. The third is whether they might contribute to abuse through the relationships connected to their activities, such as with business partners, suppliers, State agencies, and other non-State actors. How far or how deep this process must go will depend on circumstances. ${ }^{29}$

\footnotetext{
28) Respect for human rights is not only a responsibility of multinational companies but is also incumbent in equal measure on domestic companies.

29) Protect, Respect and Remedy: A Framework for Business and Human Rights, Report of the Special Representative of the Secretary-General, John Ruggie, U.N. GAOR, Human Rights Council, 8th Session, Agenda Item 3, U.N. Doc. A/HRC/8/5 (2008), paras 57-58.
} 
Thus, companies need to undertake the following four steps: 1) adopt a human rights policy; ${ }^{30}$ 2) consider the human rights implications of activities through conducting impact assessments; ${ }^{31} 3$ ) integrate the human rights policy into the company's activities, and throughout the company; ${ }^{32} 4$ ) audit performance against policies and assessments on an ongoing basis and report on this performance. ${ }^{33}$

A critical aspect of Ruggie's pillar of the corporate obligation to "respect" human rights is the human rights impact assessment ("HRIA") which bears similarities to the environmental impact assessment. The SRSG developed a report on HRIAs concerning methodological questions and making reference to various current initiatives. The International Finance Corporation ("IFC") has developed Guide to Human Rights Impact Assessment in collaboration with the Global Compact and the International Business Leaders Forum. ${ }^{34}$

Companies may find it difficult to meet the first requirement which is collecting accurate and relevant information on the target regions of their investments. In addition, companies also need support on specific detailed questions relating to, for instance, implementation of particular social standards in certain regions. Here, the UN and its specialized agencies, such as the ILO, may become the hub for training and even implementation assessments.

In his latest report, the SRSG proposes that respect of human rights by companies should also be strengthened through reporting obligations. ${ }^{35}$ The demand for transparency and credibility in business behaviour vis-à-vis human rights should be addressed via binding reporting obligations on these matters.

Finally, the SRSG is currently working to develop appropriate remedies. It is recognized that the key is to develop and strengthen judicial and non-judicial complaint mechanisms in order to improve remedies for human rights infringements committed by companies. Here, amongst non-judicial remedies, the national contact points put in place in the framework of the OECD guidelines for multinationals can be useful complaint mechanisms. But once again, it should be noted that the duty to implement and enforce human rights is primarily a duty of states which must strengthen judicial complaint mechanisms and facilitate access to them. This is important for civil society and business

30) Id. Para. 58: "For the substantive content of the due diligence process, companies should look, at a minimum, to the international bill of human rights and the core conventions of the ILO, because the principles they embody comprise the benchmarks against which other social actors judge the human rights impacts of companies".

31) Id. para. 61.

32) Id. para. 62.

33) Id. para. 63.

34) Human Rights Impact Assessments - Resolving Key Methodological Questions, Report of the Special Representative of the Secretary-General, John Ruggie, U.N. GAOR, Human Rights Council, 4th Session, Agenda Item 2, U.N. Doc. A/HRC/4/74 (2007).

35) See Business and Human Rights: Further steps toward the operationalization of the "protect, respect and remedy" framework, Doc. A/HRC/14/27, issued on 9 April 2010. 
since slow, poor and unreliable legal systems lead to legal uncertainty, to the detriment of civil society and the economic activity.

In this framework, companies should put in place their own complaint mechanisms in order to prevent and remedy their own mistakes. Companies therefore should use various avenues to come into contact with employees, consumers, local communities and all other stakeholders in order to give them the opportunity to present their complaints and respond to them.

\section{The Impact of ICSID Arbitration on the Right to Water}

During the 1990s a trend towards privatization of infrastructures emerged mostly in developing countries, some of these privatizations entailed services such as water and sewage, electricity supply or public transportation. ${ }^{36}$ Thus, foreign private investors found themselves involved in activities with a clear impact on human rights obligations incumbent upon States. Conversely, States overlooked the fact that by privatizing certain essential services there would have been no transfer of international responsibility in terms of human rights obligations.

Here, basically, some States have faced a dilemma: in order to attract more foreign private investment, they have allowed companies to charge higher bills to citizens for water with the result of breaching human rights obligations. As soon as it was not tenable anymore, Governments have issued administrative measures (such as price-freezing) against foreign private parties with the result of breaching international investment obligations and therefore lead to ICSID arbitration. It is not excessive to say that International Investment Law has encountered International Human Rights Law in such a context with trial and error policies from Governments and from water companies.

So far investment arbitrators ${ }^{37}$ have either escaped from developing a comprehensive balanced approach to such issues or, simply, as has been observed, they

36) U. Kriebaum, "Privatizing Human Rights", Transnational Dispute Management (2007) 3-5. See also S. Pannatier and O. Ducrey, "Water Concessions and Protection of Foreign Investments under International Law", in E. Brown Weiss, L. Boisson de Chazournes and N. Bernasconi-Osterwalder (eds.), Fresh Water and International Economic Law, (2005); as well as P. Thielborger, "The Human Right to Water versus Investors Rights: Double Dilemma or Pseudo-conflict?”, in P.M. Dupuy, F. Francioni and E. Petersmann (eds.), Human Rights in International Investment Law and Arbitration (2009), pp. 487 et seq.

37) See: Compañia de Aguas del Aconquija S.A. and Vivendi Universal v. Argentine Republic (ICSID Case no. ARB/97/3); Aguas Provinciales de Santa Fe, S.A., Suez, Sociedad General de Aguas de Barcelona, S.A. and Interagua Servicios Integrales de Agua, S.A. v. Argentine Republic (Case no. ARB/03/17); Aguas Cordobesas, S.A., Suez, and Sociedad General de Aguas de Barcelona, S.A. v. Argentine Republic (Case no. ARB/03/18); Aguas Argentinas, S.A., Suez, Sociedad General de Aguas de Barcelona, S.A. and Vivendi Universal, S.A. v. Argentine Republic (Case no. ARB/03/19); Azurix Corp. v. Argentine Republic (ICSID Case no. ARB/01/12); Aguas del Tunari S.A. v. Republic of Bolivia (ICSID Case no. ARB/02/3); Azurix Corp. v. Argentine Republic (ICSID Case no. ARB/03/30); SAUR International v. Argentine Republic (ICSID Case no. ARB/04/4); Anglian Water Group v. Argentine Republic, UNCITRAL arbitration filed in 2003; 
have addressed such questions in a "sporadic manner". ${ }^{38}$ Yet, investment arbitrations may raise, much more than international commercial arbitrations, fundamental issues of public interest. Despite what normally happens in international commercial arbitration, the resolution of large investment disputes cannot escape from deciding issues of public interest given the wider political and economic impact of the decision.

The right to water has come into discussion in a number of ICSID arbitrations and gives a good picture about the different interests at stake as well as the technical solutions which are progressively being developed by experts.

\subsection{The Argentinean Saga}

The case of Aguas de Aconquija v. Argentina, ${ }^{39}$ arose from the privatization of water and water services in the 1990s as a result of economic crisis in Argentina. Water and sewage facilities in the province of Tucumàn were operated by a provincial authority which, on 18 May 1995, awarded a Concession Contract to a French company, Compagnie Générale des Eaux together with its Argentine affiliate, Compañía de Aguas del Aconquija, S.A. (the Claimants or CGE). The Republic of Argentina was not, as such, a party to the Concession Contract or to the negotiations that led to its conclusion.

However, the Argentine Republic was a party to a bilateral investment treaty of July 1991 with France for the Promotion and Reciprocal Protection of Investments (hereinafter, the Argentine-French BIT or BIT). Both the Argentine Republic and France were (and are) also parties to the Convention on the Settlement of Investment Disputes between States and Nationals of Other States (ICSID Convention), which entered into force for both states prior to signature of the Concession Contract by CGE and Tucumán.

Articles 3 and 5 of the BIT provide that each of the Contracting Parties shall grant "fair and equitable treatment according to the principles of international law to investments made by investors of the other Party," that investments shall enjoy "protection and full security in accordance with the principle of fair and equitable treatment," and that Contracting Parties shall not adopt expropriatory or nationalizing measures except for a public purpose, without discrimination and upon payment of "prompt and adequate compensation."

Biwater Gauff (Tanzania) Ltd. v. United Republic of Tanzania (ICSID Case no. ARB/05/22); Impregilo S.p.A. v. Argentine Republic (ICSID Case no. ARB/07/17); Urbaser S.A. and Consorcio de Aguas Bilbao Biskaia, Bilbao Biskaia Ur Partzuergoa v. Argentine Republic (ICSID Case no. ARB/07/26).

38) M. Hirsch, "Investment and non investment obligations", in P. Muchlinskly, F. Ortino and C. Schreuer (eds.), Oxford Handbook of International Investment Law (2008), p. 163.

39) Compañia de Aguas del Aconquija S.A. and Vivendi Universal S.A. v. Argentine Republic (ICSID Case No. ARB/97/3). Award of November 21, 2000, decided by Judge Francisco Rezek (President); Judge Thomas Buergenthal and Peter Trooboff: 16 ICSID Rev. - FILJ 641 (2001); 40 ILM 426 (2001); 125 I.L.R. 1 (2004); 26 Y.B. Com. Arb. 61 (2001) (excerpts). 
Article 8 of the BIT provides that, if an investment dispute arises between one Contracting Party and an investor from another Contracting Party and that dispute cannot be resolved within six months through amicable consultations, then the investor may submit the dispute either to the national jurisdiction of the Contracting Party involved in the dispute or, at the investor's option, to arbitration under the ICSID Convention or to an ad hoc tribunal pursuant to the Arbitration Rules of the United Nations Commission on International Trade Law. However, Art. 16.4 of the Concession Contract between CGE and Tucumán provided for the resolution of all contract disputes to be submitted to the exclusive jurisdiction of the contentious administrative courts of Tucumán.

On 26 December 1996, the private investors filed a request for ICSID arbitration against the Argentine Republic. The value of the claim was 300 million USD. The ICSID arbitrators nonetheless observed that:

It is undisputed that there were serious technical and commercial deficiencies in the structure and operation of the Tucumán water and sewer system at the time of the CGE takeover. The principal problems included severe operational difficulties resulting from the inadequate and antiquated infrastructure, deferred maintenance, tariffs that inadequately reflected the cost of operations and the required provision for capital expenditures, and failures in collection from Tucumán users, both private and commercial, of a significant part of the tariffs actually imposed ${ }^{40}$

According to the Claimants, there were four categories of violations:

(1) "Acts that resulted in a fall in the recovery rate;"

(2) "Acts that unilaterally reduced the tariff rate;"

(3) "Abuses of regulatory authority;"

(4) "Dealings in bad faith." 11

In the arbitration, the Claimants asserted that all of these acts were attributable to the Argentine Republic under international law and, as such, violated Argentina's obligations under the Agreement between the Government of the Argentine Republic and the Government of the Republic of France for Reciprocal Protection and Promotion of Investments of 3 July 1991. Argentina responded that it had not participated in the agreement challenging the jurisdiction of the arbitration tribunal and stating that such a contract made no reference to the BIT or the ICSID Convention.

On 21 November 2000, the arbitrators rendered their award rejecting the objection to jurisdiction. The tribunal held that that these claims arose, in fact, from actions of the Province relating to the merits of disputes under the Concession Contract and, for that reason, were subject to initial resolution in the con-

40) ICSID Case No ARB/97/3, Award, para. 28.

41) Id., para. 63. 
tentious administrative tribunals of Tucumán. The tribunal added that the claimants should have demonstrated that the actions of Tucumàn officials amounted to a breach of the BIT and not (only) of the concession per se. Therefore, in conclusion, the ICSID arbitrators dismissed the claims for 300 Million USD of damages.

Unhappy of such a result, CGE requested annulment of the award which was granted by ICSID. ${ }^{42}$ In its application, the Claimants alleged, ex art. Article 52(3) of the ICSID Convention that: (a) the Tribunal had manifestly exceeded its powers; (b) the award had failed to state the reasons on which it was based; and (c) there had been a serious departure from a fundamental rule of procedure.

The Committee found that there was no basis for finding any departure from a fundamental rule of procedure. However, the Committee held that the Arbitral Tribunal had manifestly exceeded its powers by upholding its jurisdiction to hear the Claimants' claims brought under the BIT, but not deciding on a significant portion of those claims. Finally the Committee found that there was no need to consider the allegation of a failure to state reasons for the claims affected by an excess of powers. On these bases, on 3 July 2002, the Committee issued a decision partially annulling the Arbitral Tribunal's award of 21 November 2000.

On August 16, 2002, the Argentine Republic submitted to the Centre a request for a supplementary decision and rectification of the Committee's annulment decision on the basis of Article 49(2) of the ICSID Convention. ${ }^{43}$ After considering the request and the parties' further submissions, the Committee denied the Argentine Republic's request for a supplementary decision and granted two of the rectification requests made by the Argentine Republic.

All in all, it has emerged that a State may breach a treaty without breaching a contract and vice versa distinguishing the breach of international law which rests with ICSID arbitrators from the breach of the contract which, in this case, should have been discussed before domestic courts.

Another ICSID arbitration against Argentina, still pending according to the ICSID website, sheds more light on the issue of human rights in an international investment arbitration context. In the case Suez, Sociedad General de Aguas de Barcelona S.A. and Vivendi Universal S.A. v. Argentine Republic, ${ }^{44}$ claimants

42) ICSID Case No ARB/97/3, Decision on annulment. This time, arbitrators were Prof. James Crawford, Prof. J. Carlos Fernandez Rosas and Yves Fortier (President).

43) According to the Argentine Republic, the Committee had failed to decide upon an omission made by the Arbitral Tribunal regarding one of the arguments made by the Argentine Republic during the main arbitral proceeding. The Argentine Republic also argued that there were material errors in the decision.

44) Suez, Sociedad General de Aguas de Barcelona S.A. and Vivendi Universal S.A v. Argentine Republic (ICSID Case No. ARB/03/19). This case was originally registered by ICSID as Aguas Argentinas S.A., Suez, Sociedad General de Aguas de Barcelona S.A. and Vivendi Universal S.A. v. the Argentine Republic (ICSID Case No. ARB/03/19). On April 14, 2006, the Arbitral Tribunal issued Procedural Order No.1 Concerning the Discontinuance of Proceedings with Respect to Aguas Argentinas S.A. (available online at http://www.worldbank.org/icsid/cases/ARB-03-19-PO-NO1.pdf). The proceedings have since 
(French and Spanish shareholders) invoked, in 2003, the investor-State dispute settlement provisions in the 1993 Argentina-France and the 1991 ArgentinaSpain bilateral investment treaties (BITs). Here the main argument is that the emergency measures adopted by the Argentine authorities in late 2001 and early 2002 to fight the economic crisis, constituted a breach of the BITs and of the water and sewer concessions received in the Province of Buenos Aires.

The Tribunal, presided over by Professor Jeswald W. Salacuse (U.S.), Professor Gabrielle Kaufmann-Kohler (Switzerland) and Professor Pedro Nikken (Venezuela) after having invited the disputing parties to file their observations on the matter, received in January 2005, a request for leave to submit amicus curiae briefs by five non-governmental organizations, based in Buenos Aires and Washington, D.C. The main argument of the NGOs is that the case involved matters of public interest and fundamental rights of the people living in the area affected by the underlying dispute. Accordingly they requested access to the case record and hearings. In the absence of the parties' agreed consent in this case, under applicable ICSID Arbitration Rule 32(2) the Tribunal would have no choice but to deny the request.

The arbitrators, nonetheless, recognized that the admission of amicus curiae briefs is a "procedural question" that can be addressed under Art. 44 of the Arbitration rules. This means that the Tribunal has found legal ground to admit amicus curiae briefs, notwithstanding the classical principle according to which non-disputing parties should not be admitted in an arbitration proceeding. It also identified the basic criteria, now codified under Art. 37, para. 2 of the ICSID Arbitration Rules, under which the amicus may be admitted..$^{45}$

In this case, the Tribunal concluded that admission of amicus curiae briefs would depend on three basic criteria:

(a) the appropriateness of the subject matter of the case;

(b) the suitability of a given non-party to act as amicus curiae in that case, and

(c) the procedure by which the amicus submission is made and considered. ${ }^{46}$

continued with respect to claimants Suez, Sociedad General de Aguas de Barcelona S.A. and Vivendi Universal S.A. The case has therefore been renamed to reflect this change.

45) Art. 37, par.2, provides that: "After consulting both parties, the Tribunal may allow a person or entity that is not a party to the dispute (in this Rule called the "non-disputing party") to file a written submission with the Tribunal regarding a matter within the scope of the dispute. In determining whether to allow such a filing, the Tribunal shall consider, among other things, the extent to which: - (a) the nondisputing party submission would assist the Tribunal in the determination of a factual or legal issue related to the proceeding by bringing a perspective, particular knowledge or insight that is different from that of the disputing parties; -(b) the non-disputing party submission would address a matter within the scope of the dispute; -(c) the non-disputing party has a significant interest in the proceeding.

The Tribunal shall ensure that the non-disputing party submission does not disrupt the proceeding or unduly burden or unfairly prejudice either party, and that both parties are given an opportunity to present their observations on the non-disputing party submission".

46) Order in Response to a Petition for Transparency and Participation as Amicus Curiae of May 19, 2005, 21 ICSID Rev. - FILJ 342 (2006). 
With respect to the first criterion, the Tribunal recognised that the dispute centred around water services provided to millions of people and thus may raise a variety of complex public and international law questions, including human rights considerations. Accordingly, any decision by the Tribunal would potentially affect the manner in which water concessions operate and thus the vast public they serve.

As to the Petitioners, the Tribunal identified as factors to be considered the expertise, experience, and independence of the amicus curiae given the fact that procedural rights of the disputing parties may be affected by such submissions.

The case is still pending but some information about it has been published. It is reported that Argentina has argued that its BIT obligations must not be interpreted in a vacuum outside the rest of international law, but that BIT obligations should be read in light of other rules of international law linking Argentina, the United Kingdom, France and Spain, including "any treaty on human rights contemplating the human right to water". ${ }^{47}$

Furthermore, Argentina contends that its treatment of the claimants was motivated by various business failings on the part of Aguas Argentinas under the light of the overriding obligation to protect the population's right to water. Thus, the Argentine authorities had to intercede so as to ensure that the right to water was not undermined by third parties. In particular, Argentina quotes General Comment No. 15 on the "Right to Water", in support of its "overriding responsibility to ensure the availability of water to all members of society" and that its actions were a legitimate and proportionate response - rather than an act of indirect expropriation. ${ }^{48}$ It is also reported that the claimant water companies adduces that the human right to water is "irrelevant" to the arbitration and that the fair and equitable treatment clause of the BIT is conceived to provide a stable and predictable investment environment which ensures that an investor's legitimate and reasonable expectations are met.

A further argument is that of the state of necessity. Under this argument, a severe economic crisis could exempt a State from observing its international obligations under necessity. Therefore, any breach of the bilateral investment treaty should be excused and such a necessity should be recognized from the fact

47) See L. Petersen, <http://www.dd-rd.ca/site/_PDF/publications/globalization/HIRA-volume3-ENG. pdf>, (visited on 20 May 2010). Note that reference to human rights is also found in another arbitration concerning water and sewer services concession agreement, Azurix v. Argentina (ICSID Case No. ARB/01/12, final award of 14 July 2006) although the arbitration tribunal (Andrés RIGO SUREDA, president; with Marc LALONDE from Canada and Daniel H. MARTINS from Uruguay) has concluded that (para. 261): "The Respondent has also raised the issue of the compatibility of the BIT with human rights treaties. The matter has not been fully argued and the Tribunal fails to understand the incompatibility in the specifics of the instant case. The services to consumers continued to be provided without interruption by $\mathrm{ABA}$ during five months after the termination notice and through the new provincial utility after the transfer of service".

48) Id. 
that Argentina was hit by a financial crisis. This argument has already been rejected in another ICSID arbitration, CMS Gas Transmission Company v. Argentina on the grounds that Argentina had contributed to the crisis and disposed of other ways to react to it. ${ }^{49}$ A solution which has been followed by other ICSID arbitrators in Enron v. Argentina ${ }^{50}$ and, on a different level and ground, even by the German Constitutional Court in a very recent case. ${ }^{51}$

\subsection{Aguas del Tunari v. Bolivia: The "Water Civil War" of Cochabamba}

The second landmark ICSID case where the "water problem" violently emerged was Aguas del Tunari v. Bolivia. ${ }^{52}$

Following classical World Bank economic recipes, Bolivia started a privatization programme in 1997. The main purpose was to improve the water distribution system which was run inefficiently by the municipal company SEMAPA with the result of delivering water only to $57 \%$ of the population of Cochabamba, the third largest city in Bolivia. As a result, a 40 year water supply contract was entered in 1999 between a consortium of private companies and Bolivian Water and Electricity Superintendencies. The operation of the new private supplier started in January 2000 and soon there were violent riots to protest against the sudden increase of water prices of $35 \%$. The protests in Cochabamba

49) CMS Gas Transmission Company v. The Argentine Republic, ICSID Case No. ARB/01/8, Award of May 12, 2005, paras. 304-394, available at http://www.worldbank.org/icsid/cases/CMS_Award.pdf. See generally A. Reinisch, "Necessity in International Investment Arbitration - An Unnecessary Split of Opiniones in Recent ICSID Cases?", 8 The Journal of World Investment \& Trade (2007), pp. 191-214; A.K. Bjorklund, "Emergency Exceptions: State of Necessity and Force Majeure" in P. Muchlinski, F. Ortino and C. Schreuer (eds.), The Oxford Handbook of International Investment Law (2008), pp. 460-523.

50) Enron Corporation and Ponderosa Assets, L.P. v. Argentine Republic, ICSID Case No. ARB/01/3, Award of May 22, 2007 paras. 288 345, available at http://ita.law.uvic.ca/documents/Enron-Award.pdf. See however LG\&E Energy Corporation v. Argentina, by contrast, exempted Argentina from State responsibility on similar facts and arguments for a limited period of time (LG\&E Energy Corp., LG $\mho E$ Capital Corp., LG\&E International Inc. v. The Argentine Republic, ICSID Case No. ARB/02/1, Decision On Liability of Oct. 3, 2006, paras. 201-266, available at http://www.worldbank.org/icsid/cases/pdf/09_LGE_ Liability_e.pdf).

51) Bundesverfassungsgericht [BVerfG], Decision of May 8, 2007, available at http://www.bverfg.de/ entscheidungen/ms20070508_2bvm000103.html.

52) Aguas del Tunari v. Bolivia, ICSID case No ARB/02/3, Decision on Jurisdiction, 21 October 2005. The Decision on Jurisdiction was rendered on October 3, 2005, by a Tribunal comprised of Mr. Henri C. Alvarez, a Canadian national, appointed by the Claimant, Dr. José Luis Alberro-Semerena, a national of Mexico, appointed by the Respondent, and Professor David D. Caron, a U.S.national, appointed by the Centre pursuant to Article 38 of the ICSID Convention and Rule 4 of the ICSID Arbitration Rules. On this case see M. Mc Farland Sanchez-Moreno, T. Higgins, "No recourse: Transnational Corporations and the Protection of Economic, Social and Cultural Rights in Bolivia, 27 Fordham International Law Journal (2004) 1663; R. Glennon, Water Scarcity, Marketing and Privatization”, Texas Law Review (2005) 1873 , at 1894. 
were addressed by the Government through the military force, declaring martial law and with the tragic result of one teenager killed and about 100 people wounded.

In view of that, the private investor decided to discontinue the project and the Bolivian Government terminated the contract. The Government initially tried to reach an amicable settlement with the private investor but, after these negotiations failed, Aguas del Tunari filed a formal request for arbitration to ICSID.

Accordingly, the proceedings were commenced by Aguas del Tunari S.A. claiming that Bolivia, through various acts and omissions leading up to the termination of the Concession contract in April 2000, breached various provisions of the Agreement on Encouragement and Reciprocal Protection of Investments Between the Kingdom of the Netherlands and the Republic of Bolivia (the Netherlands-Bolivia BIT). Bolivia raised objections to jurisdiction of ICSID arbitrators on two main grounds. First, it stated that it did not consent to jurisdiction; and, second, on the ground that the Claimant was not a "national" of The Netherlands as defined in the BIT insofar as it was not "controlled directly or indirectly" by nationals of The Netherlands. In its Decision on Respondent's Objections to Jurisdiction, the Tribunal, by majority, concluded that the dispute was within the jurisdiction of the Centre and the competence of the Tribunal.

Secondly, Bolivia argued, inter alia, that the arbitration clause in the Concession Contract precluded ICSID jurisdiction; that all actions on which the Claimant based its claims, including the termination of the Concession, were taken by the Water Superintendency of Bolivia; that the BIT's Article 2 recognizes the application of Bolivian Law over the dispute. Even these arguments were ultimately rejected.

Shortly after the constitution of the Tribunal, certain individuals and environmental non-governmental organizations filed a joint petition requesting the Tribunal to grant them standing to participate as parties in the proceeding or at least that they be granted the right to participate in proceedings as amici curiae. The Tribunal concluded that the interplay of the ICSID Convention and the BIT, and the consensual nature of arbitration placed the control of such issues into the parties' hands. Since the agreement of both parties was absent in this case, the Tribunal lacked the power to join a non-party to the proceedings and, $a$ fortiori, to the public generally or even to make the documents of the proceedings public. In 2006, both parties settled their dispute. They declared that the concession was terminated because of the state of emergency in Cochabamba. Accordingly the ICSID proceeding were discontinued at the request of the Respondent. ${ }^{53}$

53) Order taking note of the discontinuance pursuant to ICSID Arbitration Rule 44 issued by the Tribunal on March 28, 2006 (see http://icsid.worldbank.org/ICSID/Index.jsp, visited on 15 May 2010). 


\subsection{Biwater v. Tanzania}

As a final example, the case of Biwater v. Tanzania ${ }^{54}$ is illustrative of the new role of amici curiae, their input to the assessment of facts and law and about how ICSID arbitrators may deal with issues involving human rights considerations.

In 2003, the Republic of Tanzania obtained funds amounting to 140 million USD from the World Bank, the African Development Bank and the European Investment Bank for a program of repairing, updating, and expanding Dar es Salaam's water and sewerage infrastructure. At the time, the water situation was precarious, i.e., water was not available in all regions, and the tariffs charged users of water were too low to fund capital expenditures. The sewerage situation was particularly bad. The funding was conditioned on having a private operator manage and operate the water and sewerage system. Accordingly, Biwater Gauff (a joint venture of two European companies, one registered in England and Wales and one registered in Germany) submitted a tender and it was awarded the bid. According to the terms of such a tender, Biwater Gauff would establish a local operating company, with a minimum number of shares to be held by a Tanzanian company or national. The operating company, City Water Services Limited, then entered into three contracts with the Dar es Salaam Water and Sewerage Authority (DAWAS).

One contract, the Water and Sewerage Lease Contract, required City Water to provide water and sewerage services for a ten-year period in a designated area and implement certain infrastructural works associated with the modernization project. By the same contract, City Water was to pay rental fees to DAWASA. City Water would collect an operator tariff, which would fund its operations; a lessor tariff, which it would turn over to DAWASA; and a first-time connection tariff, which would be placed in a trust account to fund low-income users' connection charges. In return, DAWASA gave City Water exclusive use of certain assets that City Water would lease from DAWASA, gave City Water the exclusive right to operate the designated water services, and promised not to operate in any way that would hinder or conflict with City Water's operations.

City Water commenced performance on 1 August 2003 but the infrastructure problems made it particularly difficult to bill and collect from customers for the services it provided, both because it faced unauthorized competitors and because many residents resisted the rise in the rates. A significant issue was its failure to implement the new billing process, which would help fund City Water's operations. Actually, City Water had underestimated the risks of the project and failed to allocate sufficient managerial and financial resources to it. In the end, City

54) Biwater Gauff (Tanzania) Limited v. United Republic of Tanzania (ICSID Case No. ARB/05/22), award of 24 July 2008. The arbitrators were Gary Born (USA), Toby Landau (U.K) and Bernard Hanotiau (president, Belgian). See http://icsid.worldbank.org/ICSID/FrontServlet?requestType=CasesRH\& actionVal=showDoc\&docId=DC770_En\&caseId=C67 . 
Water requested an increase in the Operator Tariff, but Tanzania rejected the request and relations between the government and Biwater Gauff continued to deteriorate.

Between 13 May 2005 and 1 June 2005, DAWASA and other government authorities terminated the lease contract, occupied City Water's facilities, took over the management and deported City Water's senior managers.

Biwater Gauff then brought a claim under the bilateral investment treaty (BIT) between the United Kingdom and the Republic of Tanzania, alleging expropriation of its property and unreasonable or discriminatory treatment. The company also claimed that Tanzania had violated its obligation to provide fair and equitable treatment and full protection and security, including a failure in permitting the repatriation of investment funds.

ICSID arbitrators granted a group of interested parties (Tanzanian and international NGOs) permission to file an amicus curiae brief in support of the Tanzanian Government. This amicus brief was filed in March 2007 and was taken into account by the Arbitration Tribunal.

In particular, the arbitrators (para. 359) have observed that:

The five Petitioners comprise NGOs with specialised interests and expertise in human rights, environmental and good governance issues locally in Tanzania. They approach the issues in this case with interests, expertise and perspectives that have been demonstrated to materially differ from those of the two contending parties, and as such have provided a useful contribution to these proceedings.

The arbitrators then (para. 366) define the role of the amici curiae with these words:

In addressing this issue, the Arbitral Tribunal noted that it was important to be clear as to the proper role of a "non disputing party", or amicus curiae in any given case. In this case, given the particular qualifications of the Petitioners, and the basis for their intervention as articulated in the Petition, it was envisaged that the Petitioners would address broad policy issues concerning sustainable development, environment, human rights and governmental policy. These, indeed, are the areas that fell within the ambit of Rule 37(2)(a) of the ICSID Arbitration Rules. Given the generalised nature of the Petitioners' interests and participation, what was not expected was that the Petitioners (a) would consider themselves as simply in the same position as either party's lawyers, or (b) that they would see their role as suggesting to the Arbitral Tribunal how issues of fact or law as presented by the parties ought to be determined (which is obviously the sole mandate of the Arbitral Tribunal itself).

The amici argue that BGT's acts and omissions caused its investment to fail and that investors in the water sector have a heightened level of responsibility because the success of a business venture in this area has a direct impact on the achievement of the right to clean and safe water. The brief further argues that taking into consideration human rights and sustainable development, the termination of the contract by a government, if done in good faith to prevent the worsening 
or abuse of human rights, should not be found to be a contractual breach, especially when a contract's purpose was to promote and enhance the achievement of such rights.

This point is illustrated in the award at para. 380 where it is stated that:

\begin{abstract}
The Amici submit that human rights and sustainable development issues are factors that condition the nature and extent of the investor's responsibilities, and the balance of rights and obligations as between the investor and the host State. They conclude that foreign corporations engaged in projects intimately related to human rights and the capacity to achieve sustainable development (such as the project here), have the highest level of responsibility to meet their duties and obligations as foreign investors, before seeking the protection of international law. This is precisely because such investments necessarily carry with them very serious risks to the population at large
\end{abstract}

Moreover, the considerations above lead to this practical conclusion (para. 381):

\begin{abstract}
Having analysed the scope and nature of investor responsibility in general, the Amici contend that, in this case, BGT failed to meet its specific responsibilities, and that it is BGT's own acts and omissions, rather than those of the Republic, which caused the investment to fail. In particular, it is said that BGT did not apply proper business standards and necessary care either in the pre-investment or the investment phases. On the Amicis analysis, BGT submitted a bid that was too low for it to be able to meet the costs of providing the water services it promised to provide. Its business plan was based on unsustainable assumptions about contractual performance, and it did not carry out proper due diligence to determine the feasibility and viability of the investment in the pre-establishment phase.
\end{abstract}

The arbitration tribunal declared that the Tanzanian Government had violated the terms of its bilateral investment treaty with the UK. However, the tribunal declined to award BGT the monetary damages requested. Even deciding about the costs of the arbitration, neither party was ordered to pay the costs incurred by the other, as both had been successful: Biwater Gauff had proven that Tanzania violated the BIT, and Tanzania, had been successful in resisting any claim for damages given the circumstances of the case.

\title{
5. Conclusion
}

In developing countries where structural adjustment loans have been contracted in the past and where global financial pressure has pushed the governments to deregulate water and privatise the sector, foreign private investments have flowered. A greater role and a greater responsibility should be placed on international financial institutions including human rights clauses in their financing instruments.

Economic globalisation has shifted some of the regulation powers of Governments - with their complicity - to private economic actors. However, it should not amount to substituting the public interest of the citizens for the private interest of a few individuals, including some corrupt governmental officials. 
The test of this decade for international investment law is when a decision needs to be made between ensuring the profits of a private investor and protecting human or environmental rights. The answer is certainly difficult, since a balance has to be made by arbitrators outside the specific context of human rights courts or international bodies. The unity of international law and not its fragmentation can provide the basis to reconcile conflicting rules.

Transparency and good governance are the other two key values of our times. While confidential business information must be protected (and this is the case in international commercial arbitration), when vital goods like water, are at stake, there should be information to the public about the terms of the privatization and its impact on the society. This would lead to more responsible contracting by companies and governments, and contribute to more consistent rulings by arbitrators, thereby reinforcing predictability and legitimacy of international law.

Last but not least, each government should consider the human rights impact in a range of broader policy areas, including when they sign trade agreements and investment treaties. What is needed, therefore, are government policies that induce greater corporate responsibility, and corporate strategies that reflect the now inescapable fact that their own long-term prospects are tightly coupled with the well-being of the society in which they operate. 